UDC 681.5.004

S. V. Burmistrov ${ }^{1}$, Ph.D., e-mail: sergijburmistrov@yandex.ua

O. M. Panasco ${ }^{2}$, Ph.D., associate professor, e-mail: lena.pa@ukr.net

D. V. Vakulenko ${ }^{1}$, 4th year student

e-mail: drsmile444@gmail.com

${ }^{1}$ Cherkasy state business-college,

V. Chornovola str., 243, Cherkasy, 18028, Ukraine

${ }^{2}$ Cherkasy State Technological University

Shevchenko blvd, 460, Cherkasy, 18006, Ukraine

\title{
MATRIX METHOD OF RECEIVING THE FULL COMPOSITION OF THE GROUPS OF RELATIVITY OF BOOLEAN FUNCTIONS
}

The article describes a matrix method for obtaining the full composition of the groups of relativity of Boolean functions on the basis of a universal permutation matrix.

This method makes it possible to obtain the full composition of the group of relativity on the basis of one Boolean function of its composition, the name of the group of relativity (the smallest binary number of Boolean function in the group), to construct the minimal form for any of Boolean functions of the group without the process of minimization if at least one function from the group of relativity is already minimized.

The phenomenon of the groups of relativity in symbolic logic is due to the problem of numerology. It is due to the fact that all arguments of Boolean function are absolutely equal, but when constructing a truth table, columns must be put in a certain order. As a result, there are large groups of functions having the same properties, because they have the same internal structure. The advantage of group data is that they completely cover the full range of Boolean functions without overlapping one another. This makes it possible to significantly reduce the number of objects studied within the complete set $L(n)$ of all Boolean functions $f(n)$ by examining only one Boolean function from the whole group.

The full composition of the group of relativity based on the truth table of the function can be formed by performing two equivalence operations - by rearranging columns of arguments in places or by replacing the arguments columns with their inverses, without changing in both cases the values in the column of the result. It is these actions that underlie the implementation of the method. To simplify the implementation of the method, recursive procedures are replaced by cyclic ones.

This method is developed as a working tool for studying the relationships between the groups of relativity in terms of the decomposition of Boolean functions in order to find new effective methods of minimization.

Keywords: Boolean function, groups of relativity, universal matrix of permutations.

Relevance of research. The problem of minimizing Boolean functions (BFs) with a large number of arguments is one of the most laborious stages in the process of synthesizing digital units (CBs) of promising computer systems.

A key step in the development of new methods for minimizing $\mathrm{BF}$ is the study and research of patterns of the structure and internal organization of $\mathrm{BF}$, as well as factors facilitating the process of their minimization.

In the research of $\mathrm{BF}$ whole groups of Boolean functions - groups of relativity (GR) [1] - are found, combining BF with the same proper- ties (see Table 1). As a result, BF data inside the group have the same circuitry [2].

The main advantage of GR is the fact that the groups of relativity cover the complete set of BFs. Therefore, the study of only one BF from the GR instead of all BFs allows for a significant acceleration of the study of a complete set of BFs.

Taking into account the importance of the groups of relativity in the systematic study of the complete set of BFs, the actual problem consists in the development of an effective method for obtaining the full composition of GR based on one of its BFs. 
Table 1

Number of groups of relativity of Boolean functions

\begin{tabular}{|c|c|c|c|}
\hline № & 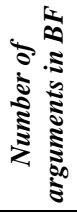 & $\begin{array}{c}\text { Number } \\
\text { of BF in } L(n)\end{array}$ & $\begin{array}{c}\text { Number } \\
\text { of relational groups in } \\
L(n)\end{array}$ \\
\hline 1 & 2 & $2^{4}=16$ & 5 \\
\hline 2 & 3 & $2^{8}=56$ & 24 \\
\hline 3 & 4 & $2^{16}=65.536$ & 402 \\
\hline 4 & 5 & $2^{32}=4.294 .967 .296$ & 1.228 .158 \\
\hline 5 & 6 & $2^{64} \approx 1,84467 \cdot 10^{19}$ & 400.507 .806 .843 .728 \\
\hline
\end{tabular}

Analysis of recent research and publications. Belarusian group of scientists under the guidance of Zakrevsky [3] pays considerable attention to the study of the properties and characteristics of BF structure. The laboratory of logical design, organized by him in 1971, gave a whole galaxy of scientists of this school: Bibilo P. N. [6], Pottosin Yu. V. [7], Cheremisinova L. D. [8], Toropov N. R. [9] and others.

Considerable attention to the research problem is given to this topic at Omsk State University [4]. Researches are conducted also in Ukraine [5]

Formulating the goals of the article. Solving the problem of minimizing $\mathrm{BF}$ with a large number of arguments based on unrepeatable Boolean functions enables to construct highperformance computer systems in positional binary numerical systems that perform arithmetic calculations similar to systems of residual classes (SOK), where each digit of the number is calculated separately without taking into account junior grades. For systematic research in this direction, there is a need to develop a simple method for the rapid acquisition of the full composition of BF in a specific GR based on one of its BFs.

The purpose of the article is to describe a developed matrix method for obtaining a complete membership of relational groups of Boolean functions.

Presenting main material. Boolean functions are a subset of logical functions that can be described using a truth table (TI BF) (Table 2).

The result column $y$ specifies the binary number of a specific BF:

$$
y=y_{n-1} y_{n-2} \ldots y_{3} y_{2} y_{1} y_{0} \text {, }
$$

where $y_{i}$ is either 0 or 1 .

\begin{tabular}{|c|c|c|c|c|c|c|c|}
\hline \multirow{2}{*}{$\begin{array}{c}\text { Line } \\
\text { number }\end{array}$} & \multicolumn{6}{|c|}{ Columns of arguments } & \\
\hline & $x_{n}$ & $\mathrm{X}_{\mathrm{n}-1}$ & $x_{n-2}$ & $\ldots$ & $\mathrm{x}_{2}$ & $\mathrm{x}_{1}$ & $\mathrm{y}$ \\
\hline 0 & 0 & 0 & 0 & $\ldots$ & 0 & 0 & $\mathrm{y}_{0}$ \\
\hline 1 & 0 & 0 & 0 & $\ldots$ & 0 & 1 & $\mathrm{y}_{1}$ \\
\hline 2 & 0 & 0 & 0 & $\ldots$ & 1 & 0 & $\mathrm{y}_{2}$ \\
\hline 3 & 0 & 0 & 0 & $\ldots$ & 1 & 1 & $\mathrm{y}_{3}$ \\
\hline$\ldots$ & $\ldots$ & $\ldots$ & $\ldots$ & $\ldots$ & $\ldots$ & $\ldots$ & $\ldots$ \\
\hline $\mathrm{n}-2$ & 1 & 1 & 1 & $\ldots$ & 0 & 1 & $\mathrm{y}_{\mathrm{n}-2}$ \\
\hline $\mathrm{n}-1$ & 1 & 1 & 1 & $\ldots$ & 1 & 0 & $\mathrm{y}_{\mathrm{n}-1}$ \\
\hline
\end{tabular}

Obviously, one BF corresponds to a specific binary number. Binary numbers allow to see all BF states, to sort and group them by properties.

In [1] it is shown that the full GR composition on the basis of TI BF can be formed by performing two equivalence operations - by rearranging columns of arguments or by replacing the columns of arguments with their inverses, without changing in both cases the values in the result of column TI BF.

The subset of the permutation of arguments contains in the general case $\boldsymbol{n}$ ! variants of Boolean functions, and the subset of the substitution of arguments by their inversions $-2^{n}$ variants of $\mathrm{BF}$. Therefore, the maximum amount of BF within one GR may be, if not taking into account the mutual overlapping of BF:

$$
N \leq n ! \cdot 2^{n} .
$$

As it follows from the formula, the number of permutations, depending on the number of arguments, grows in an avalanche way (Table 3).

The matrix method for obtaining the full membership of the groups of the relativity of Boolean functions is based on the use of a universal permutation matrix. The versatile matrix of permutations is a table whose rows are all variants of permutations obtained as a result of permutations of columns and inversion of arguments in TI BF. Elements of the matrix are the index numbers of the binary number $\mathrm{BF}$.

The method of obtaining the full membership of GR consists of two stages:

1. Preparatory stage - the stage of obtaining a universal matrix of permutations. The universal matrix is unique to BFs that contain a specific number of arguments. Therefore, it is built once and used in the future for the full GR. 
The size of the permutations matrix for $B F$ containing $n$ arguments

\begin{tabular}{|c|c|c|c|}
\hline \multirow{2}{*}{ № } & \multirow{2}{*}{ 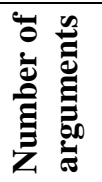 } & \multicolumn{2}{|c|}{ Matrix size } \\
\hline & & $\begin{array}{c}\text { Number of } \\
\text { characters per line }\end{array}$ & $\begin{array}{l}\text { Number } \\
\text { of rows }\end{array}$ \\
\hline 1 & 2 & 4 & 8 \\
\hline 2 & 3 & 8 & 48 \\
\hline 3 & 4 & 16 & 384 \\
\hline 4 & 5 & 32 & 3840 \\
\hline 5 & 6 & 64 & 46080 \\
\hline 6 & 7 & 128 & 645120 \\
\hline 7 & 8 & 256 & 10321920 \\
\hline 8 & 9 & 512 & 185794560 \\
\hline 9 & 10 & 1024 & 3715891200 \\
\hline 10 & 11 & 2048 & 81749606400 \\
\hline 11 & 12 & 4096 & 1961990553600 \\
\hline 12 & 3 & 8192 & 51011754393 \\
\hline
\end{tabular}

At the preparatory stage, one must first build a complete list of permutations of columns of arguments in places and inversions of columns of arguments in TI BF. Then, for each combination of arguments, the corresponding binary index number BF should be constructed.

The algorithm for obtaining a universal matrix of permutations has the form (Fig. 1).

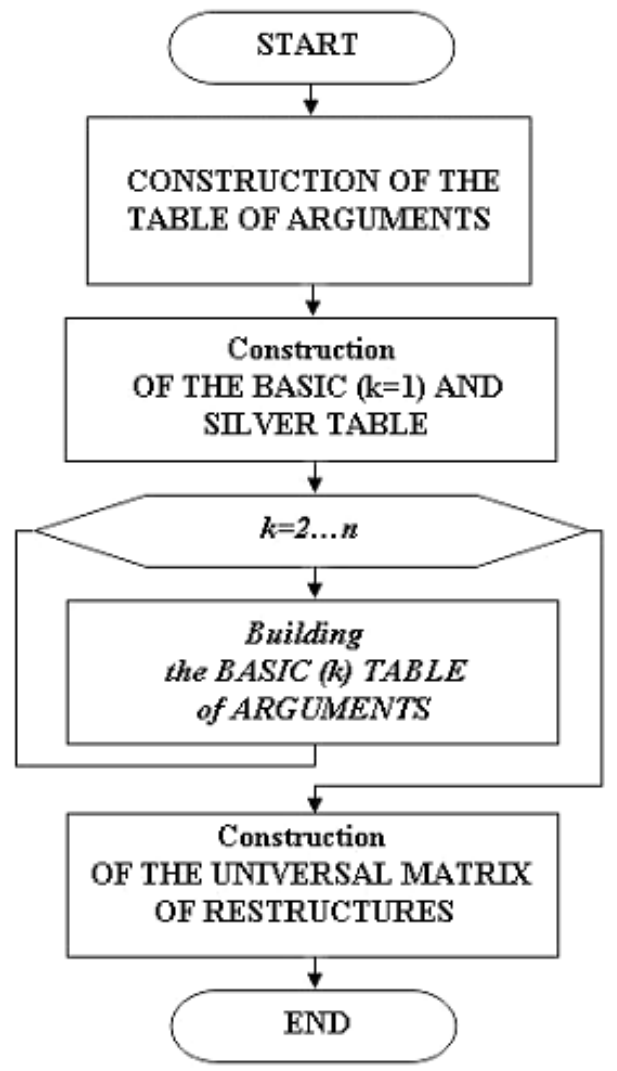

Fig. 1. Algorithm for obtaining a universal matrix of permutations
A universal matrix of permutations, the lines of which are indexes of the binary number $\mathrm{BF}$, is the result of the preparatory stage. For BFs containing two arguments, it has the form (Table 4).

Table 4

\section{Universal matrix for permutations for BF containing two arguments}

\begin{tabular}{|r|rrrr|}
\hline $\begin{array}{c}\text { Combination } \\
\text { options }\end{array}$ & \multicolumn{4}{|c|}{$\begin{array}{c}\text { Index in binary } \\
\text { number BF }\end{array}$} \\
\hline 1 & 3 & 2 & 1 & 0 \\
\hline 2 & 3 & 1 & 2 & 0 \\
\hline 3 & 2 & 3 & 0 & 1 \\
\hline 4 & 1 & 3 & 0 & 2 \\
\hline 5 & 1 & 0 & 3 & 2 \\
\hline 6 & 2 & 0 & 3 & 1 \\
\hline 7 & 0 & 1 & 2 & 3 \\
\hline 8 & 0 & 2 & 1 & 3 \\
\hline & & & & \\
\hline
\end{tabular}

2. The main stage - Stage of getting the full membership of $G R$.

To obtain the full membership of GR in the zero line of the universal permutation matrix, one must place the binary number of BF from the desired GR (Table 5) and, by index, construct all the BFs from the given GR.

Table 5

Application of a universal matrix of permutations for building a complete GR

\begin{tabular}{|c|c|c|c|c|c|}
\hline № & \multicolumn{4}{|c|}{ BF Binary Number } & \multirow{3}{*}{ Result } \\
\hline 0 & 0 & 1 & 0 & 1 & \\
\hline & \multicolumn{4}{|c|}{$\begin{array}{c}\text { Index in BF binary } \\
\text { number } B F\end{array}$} & \\
\hline 1 & 3 & 2 & 1 & 0 & 0101 \\
\hline 2 & 3 & 1 & 2 & 0 & 0011 \\
\hline 3 & 2 & 3 & 0 & 1 & 1010 \\
\hline 4 & 1 & 3 & 0 & 2 & 1100 \\
\hline 5 & 1 & 0 & 3 & 2 & 0101 \\
\hline 6 & 2 & 0 & 3 & 1 & 0011 \\
\hline 7 & 0 & 1 & 2 & 3 & 1010 \\
\hline 8 & 0 & 2 & 1 & 3 & 1100 \\
\hline
\end{tabular}

As a result, for the given BF 0101 the GR has been received with four BFs: 0011, 0101, 1010, 1100. The GR has the smallest number of BFs - 0011 . 


\section{Conclusions:}

1. The phenomenon of the groups of relativity in symbolic logic is due to the problem of numerology. It is due to the fact that all arguments in BF are absolutely equal, but when constructing $\mathrm{TI} \mathrm{BF}$, they need to be put in a certain order.

2. A matrix method for obtaining a full composition of the groups of relativity of Boolean functions is developed in the article on the basis of a universal permutation matrix.

3. This method makes it possible to obtain the name of GR (the smallest binary number BF in GR), the complete GR composition based on one $\mathrm{BF}$ of its composition, to construct a minimal form for any of BFs from the GR without the minimization process, if at least one BF is already minimized from GR.

4. This method is a working tool for investigating the interrelationships between GRs in terms of BF decomposition. This makes it possible to significantly reduce the number of objects studied within the complete set $L(n)$ of all BFs $f(n)$ by examining only one BF from the entire group.

\section{References}

1. Bibilo, P. N. (2009) Decomposition of Boolean functions based on solving logical equations. Minsk: Belarussian Nuclei. $211 \mathrm{p}$. ISBN 978-985-08-1072-4

2. Kochkarev, Yu. A., Panteleev, N. N., Kazarinova, N. L. (1999) Classical and alternative minimal forms of logical functions: Catalog reference book: monograph. G. E. Pukhov
Institute for Modeling Problems in the Energy, Cherkasy Institute of Management. Cherkasy. 195 p.

3. Bibilo, P. N., Pottosin, Yu. V., Cheremisinova, L. D. (2017) On the scientific heritage of Corresponding Member A. D. Zakrevsky. Informatics. Joint Institute for Informatics Problems of the National Academy of Sciences of Belarus. No. 1 (53). January-March. P. 112-124.

4. Filippov, V. M., Manokhina, T. V., Evdokimov, A. A., Sajats, D. S. (2016) Minimization of functions of the algebra of logic by the method of a non-directed graph. International Journal of Applied and Fundamental Research. Technical sciences. No. 8. P. 509-511.

5. Alekseychuk, A. N., Konyushok, S. N. (2014) The algebraically degenerate approximation of Boolean functions. Cybernetics and system analysis. No. 6. P. 112-124.

6. Bibilo, P. N. (2014) Application of binary selection diagrams in the synthesis of logic circuits. Minsk: Belarussian Nuclear. 231 p.

7. Pottosin, Yu. V. (2015) Energy-saving anticonvoy coding of states of asynchronous automaton. PDM Annex. No. 8. P. 120-123.

8. Cheremisinova, L. D., Novikov, D. Ya. (2008) Verification of the scheme realization of partial Boolean functions. Bulletin of Tomsk State University. Management, Computing and Informatics. No. 4 (5). P. 102-111.

9. Zakrevsky, A. D., Toropov, N. R. (2009) Minimization of Boolean functions of many variables in the DNF class-iterative method and program realization. PDM. Annex. No. 1 (3). P. 5-14.

\section{С. В. Бурмістров ${ }^{1}$, $к . m . н$. , e-mail:sergijburmistrov@yandex.ua О. М. Панаско ${ }^{2}$, к.т.н., доиент, e-mail: lena.pa@ukr.net \\ Д. В. Вакуленко ${ }^{1}$, студент 4-го курсу e-mail: drsmile444@gmail.com \\ ${ }^{1}$ Черкаський державний бізнес-коледж, вул. В. Чорновола, 243, м. Черкаси, 18028, Україна \\ ${ }^{2}$ Черкаський державний технологічний університет б-р Шевченка, 460, м. Черкаси, 18006, Україна \\ МАТРИЧНИЙ МЕТОД ОТРИМАННЯ ПОВНОГО СКЛАДУ ГРУП РЕЛЯТИВНОСТІ БУЛЕВИХ ФУНКЦЙ}

У статті описано матричний метод отримання повного складу груп релятивності булевих функиій на основі універсальної матрииі перестановок. Цей метод дає можсливість отримати повний склад групи релятивності на основі однієї булевої функиії із ї̈ складу, назву групи 
релятивності (найменший бінарний номер булевої функції в групі), побудувати мінімальну форму для будь-якої булевої функції зі складу групи без виконання процесу мінімізаиії, якщзо вже мінімізована хоча б одна функиія зі складу групи релятивності.

Це дає можливість суттєво зменшити кількість досліджуваних об'єктів у межах повної множини L(n) всіх булевих функиій $f(n)$, досліджуючи лише одну булеву функиію з усієї групи. Для спрощення реалізачії методу рекурсивні прочедури замінено на ииклічні.

Цей метод розроблено як робочий інструмент для дослідження взаємозв'язків між групами релятивності з точки зору декомпозииії булевих функиій для пошуку нових ефективних методів мінімізаиії.

Ключові слова: булева функиія, групи релятивності, універсальна матриця перестановок.

Стаття надійшла до редакиії 07.09.2018.

Рецензенти: В. М. Рудницький, д.т.н., професор,

С. В. Голуб, д.т.н., професор. 